\title{
Decolorization of Acid Green 25 by Surface Display of CotA laccase on Bacillus subtilis Spores
}

\author{
Jong-Hwa Park ${ }^{1 \dagger}$, Wooil Kim ${ }^{1 \dagger}$, Yong-Suk Lee ${ }^{2}$, and June-Hyung Kim ${ }^{1,3 *}$ \\ ${ }^{1}$ Department of Chemical Engineering, Dong-A University, Busan 49315, Republic of Korea \\ ${ }^{2}$ Department of Biotechnology, Dong-A University, Busan 49315, Republic of Korea \\ ${ }^{3}$ Center for Sliver-Targeted Biomaterials, Brain Busan 21 Plus Program, Graduate School, Dong-A University, Busan 49315, Republic of Korea
}

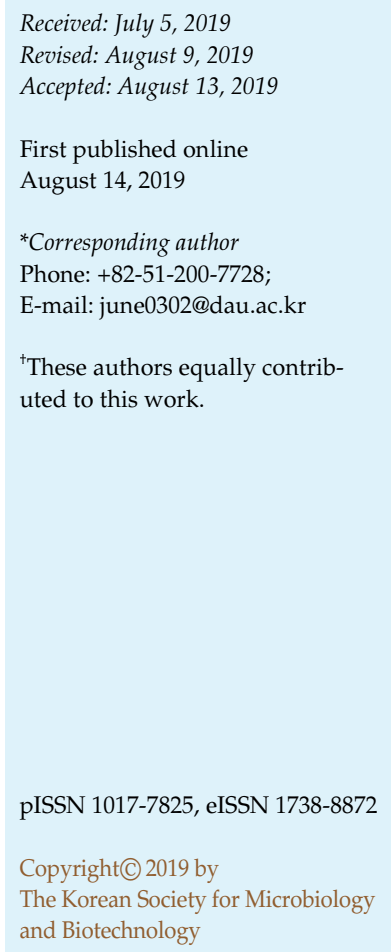

\section{Introduction}

Approximately 10,000 different dyes and pigments are used industrially, and over $7 \times 10^{5}$ tons of synthetic dyes are produced annually worldwide [1, 2]. Synthetic dyes are extensively used in textile dyeing, paper printing, color photography, pharmaceutical, food, cosmetics, and other industries [3]. Approximately 128 tons of dye wastewater is discharged daily and high cost is incurred for its removal. Wastewater remediation is challenging because it contains a variety of pollutants and it is difficult to change the composition of the contaminants.

Physical, chemical, and biological methods have been widely used to decolorize dye wastewater [4]. The physical and chemical treatment methods are preferred over other methods; however, these methods require high operating cost and other accessory equipment. It would be desirable to develop a new decolorization method that is efficient and cost effective to reduce the overall cost of dye wastewater treatment.

Recently, many studies have been published on the decolorization of synthetic dyes by laccase $[5,6]$. Laccase was first discovered in 1883 from Rhus vernicifera, the Japanese lacquer tree [7]. Laccases (benzenediol: oxygen oxidoreductase; E.C. 1.10.3.2) are a family of multi-copper oxidases (MCOs) that require oxygen to oxidize organic compounds-particularly phenols and non-phenolic aromatic substrates-by one-electron transfer to form reactive radicals, 
while reducing molecular oxygen to water [8,9]. Laccases are widespread in nature and are found in plants and fungi [10]. However, bacterial laccase was first discovered in 1993 [11]. Since then, an increasing number of studies have shown that laccases are widespread among bacteria [12]. Laccase-like activity has been found in Pseudomonas syringae (copA) [13], Xanthomonas campestris (copA) [14], Azospirillum lipoferum [15], Streptomyces griseus (epoA) [16], Escherichia coli (yacK) [17], and Bacillus subtilis $(\cot A)$ [18]. Several studies have recently reported on the decolorization of synthetic dyes, including indigo carmine by Streptomyces coelicolor [19], congo red by Bacillus sp. [20], Reactive Black5 by Shewanella oneidensis WL-7 [21], and Reactive Blue by Pseudomonas sp. [22]. A recent study tested the efficacy of $\cot A$ on several synthetic dyes owing to its wide range of substrate specificity [23].

The bacterial surface display system was first introduced in 1986 [24]. Since then, this breakthrough technology has been generating promising opportunities for several applications, including bacterial vaccines, production of active enzymes and antibodies for cleanup of industrial and environmental pollution, screening of peptide libraries and use of peptides as biosensors and biocatalysts for bioconversion [25]. The bacterial surface display system can use bacterial surface proteins as surface anchoring motifs to express exogenous proteins [26, 27].

Several gram-positive and gram-negative bacteria expression systems have been developed until now. All bacterial surface display systems rely on the secretion of the fusion protein (anchoring motif-passenger protein) across the cell membrane or cell wall. However, protein transport across the cell membrane can be difficult to achieve if the passenger protein exists as a multimer, exhibits host cell toxicity upon expression, or has a high molecular weight.

Bacillus subtilis has developed a survival strategy to transfer genetic material to the next generation by forming endospores. The mother cell invaginates into a pre-spore and various sporulation proteins in the mother cell form spores by generating multiple outer coat layers [28]. Once the spores are sufficiently formed, the mother cell starts to decompose and release them to the external environment [29].

The spore-based surface display system can solve the problems associated with the bacterial surface display system. During sporulation, coat proteins are expressed in the mother cell and subsequently localize on the surface of the developing spore to form a multilayer coat. At the end of the sporulation process, the mother cell will lyse and the spore will be released into culture medium, with fusion protein embedded on it. This means spore will serve as a display vehicle of fusion protein, which does not need the secretion mechanism of the mother cell across the cellular membrane or cell wall structure.

The spores formed by these systems are generally stronger than the normal vegetative cells in terms of exhibiting thermal, chemical, and radiation resistance [30].

In this study, we attempted to decolorize synthetic dye by displaying $\cot A$ laccase on the surface of $B$. subtilis spores. $\cot A$ is a coat protein involved in the sporulation of $B$. subtilis and it displays similarities with multicopper oxidases.

\section{Materials and Methods}

\section{Strains, Media, and General Procedures}

The two protease-deficient B. subtilis DB104 strain (his, nprR2, $n p r E 18, \triangle a p r A 3)$ was used as the bacterial host for expression

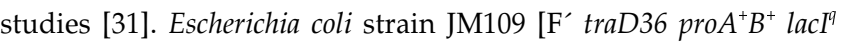
$\Delta$ (lacZ)M15/ $\Delta$ (lac-proAB) glnV44 e14- gyrA96 recA1 relA1 endA1 thi $h s d R 17]$ was used for genetic manipulation. Bacterial cultures were grown in Schaeffer's medium containing $8 \mathrm{~g}$ nutrient broth (Difco), $0.25 \mathrm{~g} \mathrm{MgSO}_{4} \cdot 7 \mathrm{H}_{2} \mathrm{O}$, and $1 \mathrm{~g} \mathrm{KCl} / \mathrm{L}$. After autoclaving, the medium was supplemented with $1 \mathrm{ml}$ of each filtered stock solution $\left(10 \mathrm{mM} \mathrm{FeSO} \cdot \cdot 7 \mathrm{H}_{2} \mathrm{O}, 10 \mathrm{mM} \mathrm{MnCl} \cdot 4 \mathrm{H}_{2} \mathrm{O}\right.$, and $1 \mathrm{M}$ $\left.\mathrm{CaCl}_{2} \cdot 2 \mathrm{H}_{2} \mathrm{O}\right)$ and chloramphenicol $(20 \mu \mathrm{M})$. Bacterial cultivation was carried out by shaking $100 \mathrm{ml}$ of Schaeffer's medium in a $250 \mathrm{ml}$ flask at $180 \mathrm{rpm}$ for $24 \mathrm{~h}$ at $37^{\circ} \mathrm{C}$.

The Hybrid-Q Plasmid Mini-prep Kit and the Expin PCR and Gel Purification Kit were purchased from GeneAll (Korea). Taq DNA polymerase was purchased from Bioneer (Korea). The restriction enzyme and T4 ligase were purchased from Takara (Japan). Anti-His 6 tag-FITC conjugated antibody was purchased from Komabiotech (Korea) for flow cytometry analysis. Goat antimouse IgG-HRP for western blot was purchased from Santa Cruz Biotechnology (USA). Acid Green 25 and all other reagents were purchased from Sigma-Aldrich (USA).

\section{Construction of Fusion Protein Expression Vector}

The anchoring motif-containing expression vector was constructed with a PCR product using B. subtilis chromosome as a template, containing each promoter and structural gene of $\cot E, \cot G$, and $\cot Y$ along with a C-terminal linker (Gly-Gly-Gly-Gly-Ser). The following primers were used for PCR:

$\cot$-5' $5^{\prime}$ AACCGGATCCACCTGCTGAAAGGGGAAAC

cotE-3': AGACCTGCAGGCTCCCTCCCCCCCCAGATCTGACGT CTTCTTCAGGATCTCCCAATA

cotG-5': GCCTTTGGATCCAGTGTCCCTAGCTCCGAG

cotG-3': CTATTGCTGCAGTGAACCCCCACCTCCTTTGTATTT CTTTTTGACTA,

$\cot Y-5^{\prime}$ : TCGTAGGGATCCTAGTTATCACTCTTGTCC

$\cot Y-3^{\prime}$ : GTTTGGCTGCAGACTCCCCCCTCCACCGGTACCTCC ATTGTGATGATG. 
Each PCR product was digested with BamHI and PstI and ligated into the same enzyme-digested pCSK1 to yield pSDJH100 (pSDJH-CotE), pSDJH200 (pSDJH-CotG), pSDJH300 (pSDJHCotY). The pCSK1 vector was derived from $\mathrm{pHP} 59$, which is a low copy E. coli/B. subtilis shuttle vector described by [32].

The thermal cycling conditions for PCR were as follows: an initial denaturation step at $95^{\circ} \mathrm{C}$ for $10 \mathrm{~min}$, followed by 30 cycles of denaturation at $95^{\circ} \mathrm{C}$ for $1 \mathrm{~min}$, annealing at $68^{\circ} \mathrm{C}$ for $1 \mathrm{~min}$, and extension at $72^{\circ} \mathrm{C}$ for $1 \mathrm{~min}$, with a final extension at $72^{\circ} \mathrm{C}$ for $10 \mathrm{~min}$.

Two primers were used for PCR amplification of $\cot A$ laccase ( $\cot A$-PstI-5': GGACAGCTGCAGATGACACTTGAAAAATTTGTGG and $\cot A$-HindIII-his ${ }_{6}$ tag-SalI-3': AAAAACGTCGACTCAGTG GTGATGGTGGTGGTGAAGCTTATGGGGATCAGTTATATCCAT CGGTCTC). The PCR product was digested with PstI and SalI, and ligated into the same enzyme-digested pSDJH100, pSDJH200, and pSDJH300 to yield pSDJH-EA, pSDJH-GA, and pSDJH-YA, respectively. The two-step (SP I, SP II) method was used for the transformation of each plasmid into B. subtilis DB104, and chloramphenicol $(5 \mu \mathrm{M})$ was used for the selection.

\section{Spore Purification Method}

Bacillus subtilis DB104 strain and recombinant cells were grown in Schaeffer's media for $24 \mathrm{~h}$ at $37^{\circ} \mathrm{C}$ and harvested by centrifugation $\left(7,224 \times g, 10 \mathrm{~min}\right.$, and $\left.4^{\circ} \mathrm{C}\right)$. Vegetative cells, sporulating cells, and spores were harvested and purified using the Renografin (sodium diatrizoate, S4506, Sigma) gradient method. Purified spores were confirmed under the microscope.

\section{Western Blot Analysis}

Purified spores were suspended in distilled water and heated to $100^{\circ} \mathrm{C}$ for 8 min with $5 \times$ sample buffer to extract the outer coat layer of B. subtilis spores. Following centrifugation at $12,225 \times g$ for $10 \mathrm{~min}$, the extracted coat protein in the supernatant fraction was separated using sodium dodecyl sulfate-polyacrylamide gel electrophoresis (SDS-PAGE) on a 10\% gel and transferred to a polyvinylidene difluoride (PVDF) membrane (Millipore, USA).

The membrane was blocked with skim milk for $10 \mathrm{~min}$, washed and incubated with a 1:1,000 diluted anti-His ${ }_{6}$ tag antibody monoclonal antibody (H1029, Sigma) for $30 \mathrm{~min}$, and washed three times with TBST (Tris-buffered saline, $0.1 \%$ Tween 20) buffer for $5 \mathrm{~min}$. The membrane was subsequently incubated with anti-mouse horseradish peroxidase (HRP)-conjugated secondary antibody (sc-2031, Santa Cruz) at a dilution of 1:2,000 for $20 \mathrm{~min}$, washed three times with TBST buffer, and visualized using ECL western blotting detection reagents. Specific bands were visualized on a film (LAS 3000, Fuji Film).

\section{Flow Cytometry Analysis}

Purified spores were washed three times with phosphatebuffered saline (PBS) solution for immunofluorescence staining. The washed spores were resuspended in $1 \mathrm{ml}$ PBS solution containing anti-His ${ }_{6}$ tag-FITC labeled antibody (1:500) (Komabiotech,
Korea) and incubated for $1 \mathrm{~h}$ on ice. Thereafter, they were washed three times with PBS, resuspended in $500 \mu \mathrm{l}$ PBS [32], and examined under a flow cytometer (Beckman Coulter Epics, UK).

\section{Decolorization Assay}

Synthetic dye was prepared in sterilized $0.1 \mathrm{M}$ sodium acetate buffer [pH 5.0]. The reaction was initiated with $3 \mathrm{mg}$ of each purified spore in a $20 \mathrm{ml}$ volume and incubated at $37^{\circ} \mathrm{C}$ with shaking at $180 \mathrm{rpm}$. The concentration of Acid Green 25 was $100 \mu \mathrm{M}$ and its absorbance was measured by UV-210PC spectrometer (Dong-il, Japan) at $640 \mathrm{~nm}$. Decolorization activity was calculated as follows: decolorization $(\%)=[$ (initial absorbance $)-($ observed absorbance)/(initial absorbance)] $\times 100$ [33].

For the inhibition study of laccase, $0.25 \mathrm{M}$ EDTA (ethylenediamine tetraacetic acid), $50 \mathrm{mM}$ SDS (sodium dodecyl sulfate), and $50 \mathrm{mM}$ $\mathrm{NaN}_{3}$ (sodium azide) were used.

To evaluate the decolorization possibility of other synthetic dyes, Acid Red 18 (azo dye) and indigo carmine (indigo dye) were used as representative dyes with different structures from Acid Green 25 (anthraquinone dye). The absorbances of Acid Red 18 and indigo carmine were measured at $510 \mathrm{~nm}$ and $610 \mathrm{~nm}$, respectively. The starting concentration for the reactions of both synthetic dyes was $50 \mu \mathrm{M}$.

\section{Effect of Temperature on Laccase Activity}

The thermal stability of spore surface-displayed $\cot A$ was determined in $0.1 \mathrm{M}$ sodium acetate buffer [pH 5.0] following incubation for $5 \mathrm{~h}$ at $20^{\circ} \mathrm{C}, 30^{\circ} \mathrm{C}, 40^{\circ} \mathrm{C}, 50^{\circ} \mathrm{C}, 60^{\circ} \mathrm{C}$, and $70^{\circ} \mathrm{C}$. The decolorization rate was calculated for absorbance reduction.

\section{Results and Discussion}

\section{Construction of Expression Vector and Recombinant B. subtilis Strain}

For the surface display of $\cot A$ laccase on $B$. subtilis spores, $\cot E, \cot G$, and $\cot Y$ were selected as anchoring motifs, not only because of their localization on B. subtilis spores, but also due to their relative abundance over other spore coat proteins [34].

CotE is a major coat protein involved in spore formation and is needed for the assembly of the outer coat protein. CotE is a $20.8 \mathrm{kDa}$ protein that guides the assembly of a major subset of coat proteins [35]. Owing to its abundance in the spore coat layer, it has been used as an efficient anchoring motif for displaying bacterial beta-galactosidase and bacterial tyrosinase [36, 37].

Cot $G$ is another major morphogenetic coat protein, located in the outer coat layer of B. subtilis spore. CotG is a $24.0 \mathrm{kDa}$ protein [38] that recruits a small subset of proteins to the coat [39]. CotG was selected as an anchor protein for this study because it has been studied extensively [34]. The 


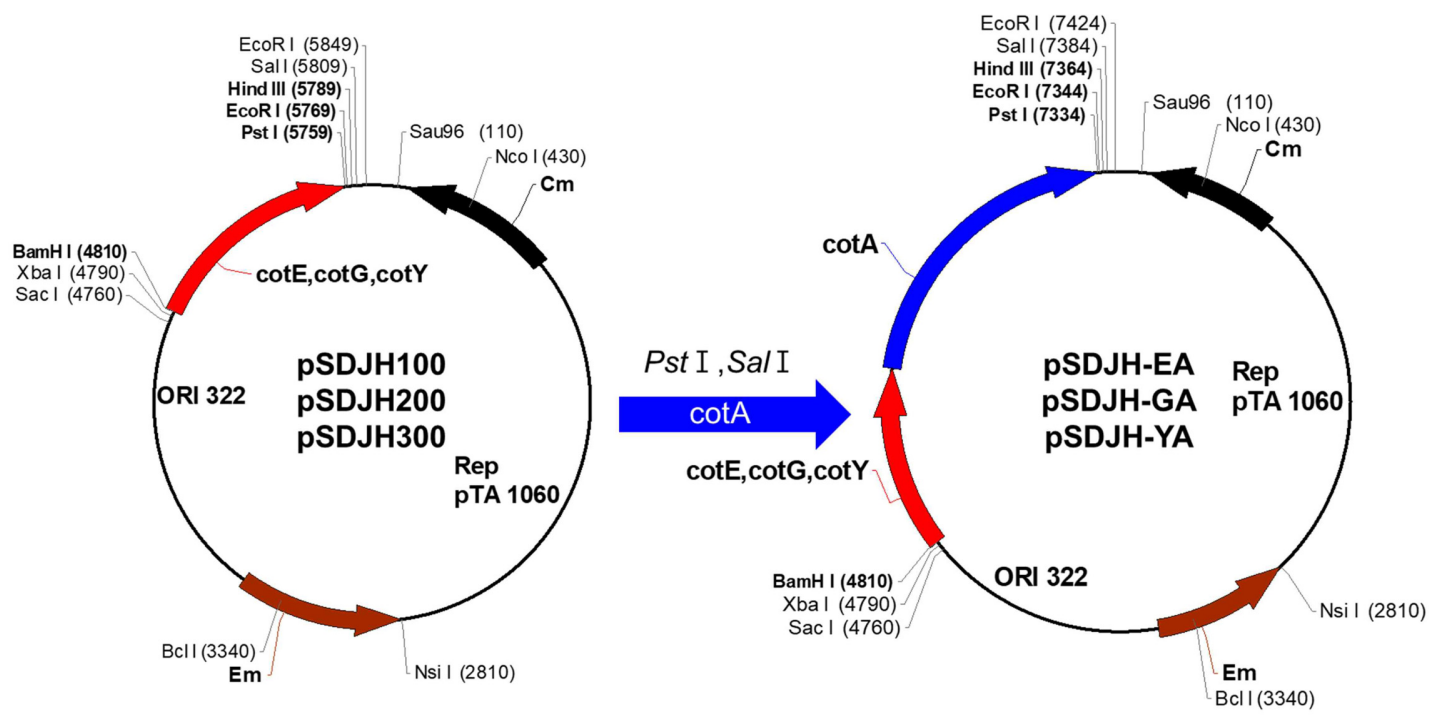

Fig. 1. Construction of pSDJH-EA, pSDJH-GA, pSDJH-YA expression vector.

Each fusion protein is expressed under original $\cot E, \cot G$ and $\cot Y$ promotor. And flexible linker (Gly-Gly-Gly-Gly-Ser) was inserted between each anchoring motif and $\cot A$ laccase. And $\mathrm{His}_{6}$ tag sequence was inserted at the C-terminal of $\cot A$ laccase for the western blot and flow cytometry.

proteins expressed using CotG as an anchoring motif include streptavidin [29], $\omega$-transaminase [40], chitinase [41], and L-arabinose isomerase [42].

CotY is located in the outermost layer of the spore, which is a newly defined crust layer [43]. CotY is a $17.7 \mathrm{kDa}$ protein that plays a morphogenetic role in crust assembly around the spore [44]. To our knowledge, only one report exists on CotY for surface display of $\beta$-galactosidase [45].

The endospore coat component of $B$. subtilis, known as $\cot A$, is the most studied bacterial laccase. The $\cot A$ gene encodes an approximately $65 \mathrm{kDa}$ monomeric protein that localizes in the outer spore coat. The high proline content of $\operatorname{Cot} A$ contributes to the thermostability of laccase [46]. CotA participates in the biosynthesis of the characteristic brown spore pigment, which protects from UV light [47].

In this study, CotA was used as the target protein to decolorize synthetic dye due to its thermostability under harsh environmental conditions; moreover, dye decomposition occurs in these conditions. The construction of vectors is shown in Fig. 1. These expression vectors were named pSDJH-EA, pSDJH-GA, and pSDJH-YA.

\section{Verification of Surface Expression of Fusion Protein}

Surface expression of the fusion protein on B. subtilis spore was verified by flow cytometry (Fig. 2). Purified spores of recombinant DB104 (pSDJH-EA), DB104 (pSDJHGA), DB104 (pSDJH-YA), and DB104 were incubated with the anti-His ${ }_{6}$ tag-FITC antibody. Although all recombinant spores showed significantly improved fluorescence intensity over the control spore of DB104, CotY served as the most effective anchoring motif for the display of $\cot A$ laccase. This is because CotY is located in the crust layer, which is the

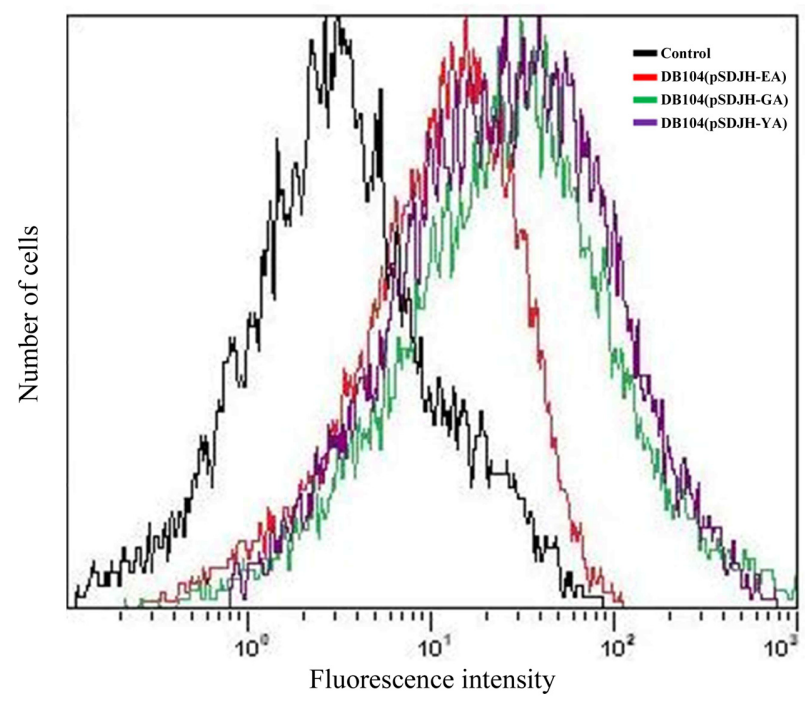

Fig. 2. Flow cytometry of purified spores of B. subtilis DB104 and each recombinant spore. DB104 spore and DB104 recombinant spore were stained with FITC-labeled his tag $_{6}$ antibody and examined under flow cytometry. 
outermost part of the spore coat; this result compared to CotE and CotG, also corresponds to the previous result [43].

The appropriate expression of fusion proteins under their native promoters and their incorporation into B. subtilis spores was confirmed by western blot with the extracted fraction of each recombinant spore. We confirmed the expected sizes of CotE-CotA (74 kDa), CotG-CotA (76 kDa), and CotY-CotA (73 kDa). No similar band was detected for the DB104 spore (data not shown). These results suggest that each fusion protein is appropriately expressed and localized in the outer coat layer of the spore, and can be extracted using a simple extraction method, as described in this study.

\section{Laccase Activity}

Synthetic dyes have been classified according to their chemical structure-such as anthraquinone, azo, indigo, nitro, phthalein, triphenyl methyl, and nitrated dyes-or their industrial application [48].

Acid Green 25 [49], an anthraquinone dye, was used to

A

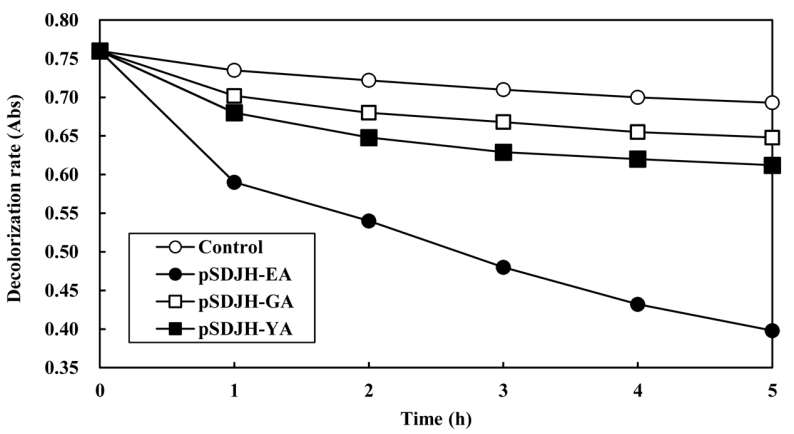

B

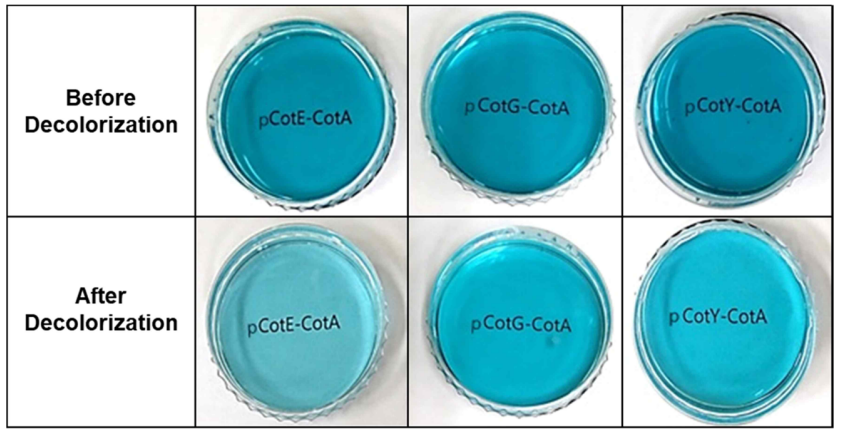

Fig. 3. (A) Comparison of laccase activity of DB104 and each recombinant spore on Acid Green 25. The decolorization of Acid Green 25 by DB104 spore was $9.9 \%$, decolorization by recombinant spore was $48.7 \%$ by DB104 (pSDJH-EA), $16.1 \%$ by DB104 (pSDJH-GA) and 21.1\% by DB104 (pSDJH-YA) after $5 \mathrm{~h}$. (B) The top photo is before decolorization and the bottom is after decolorization. evaluate the decolorization activity of laccase localized on the spore surface. After a $5 \mathrm{~h}$ reaction, the decolorization extent of Acid Green 25 by DB104 (pSDJH-EA), DB104 (pSDJH-GA), DB104 (pSDJH-YA), and DB104 spores were $48.7 \%, 16.12 \%, 21.1 \%$, and $9.9 \%$, respectively (Fig. 3A). The degree of decolorization of Acid Green 25 was also visualized (Fig. 3B). The reason for decolorization of Acid Green 25 by DB104 spore is the inherent $\cot A$ of the host strain, which is expressed by $B$. subtilis chromosomes. However, the three recombinant spores have higher decolorization activity than the control DB104 spore because of the relative abundance of surface displayed CotA protein.

Considering that the recombinant DB104 (pSDJH-EA) spore showed the highest decolorization of Acid Green 25, the decolorization of a representative azo dye, Acid Red 18 [50], and a representative indigo dye, indigo carmine [51], was measured. The decolorization rates of the DB104 (pSDJH-EA) spore for Acid Green 25, Acid Red 18, and indigo carmine were $48.7 \%, 18.5 \%$, and $43.2 \%$, respectively (Fig. 4)

Several dyes including indigo carmine and orange $G$ were decomposable with extracellularly expressed $\cot A$ laccase [52]. Congo red, Coomassie Brilliant Blue R, and crystal violet were decolorized by intracellularly expressed $\cot A$ laccase [53]. Malachite Green, Acid Blue 62, and methyl orange were also decolorized by surface-displayed $\cot A$ laccase using E. coli. [23] Until now, we could not find any tendency of the decolorizing activity toward structurally different synthetic dyes, which could be attributed to the broad enzyme specificity of $\cot A$ laccase [54].

\section{Effect of Inhibitors on Laccase Activity}

Laccase contains four copper ions that accept and transfer electrons to reduce molecular oxygen; therefore, laccase is susceptible to agents that chelate or reduce copper ions [55].

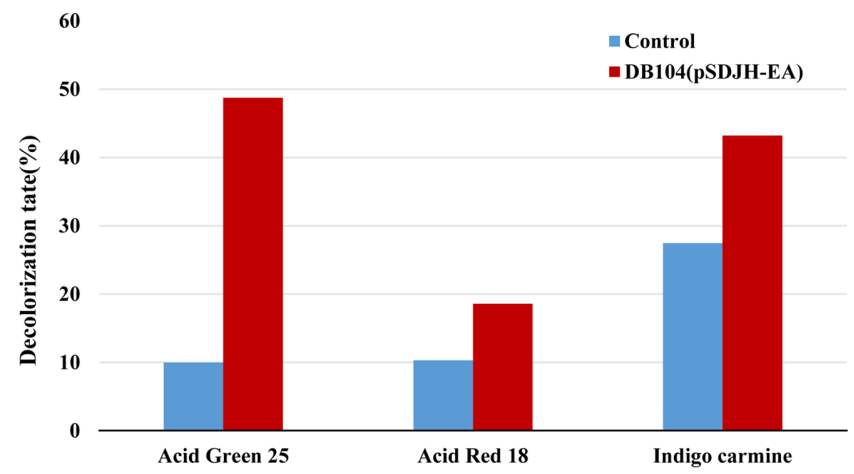

Fig. 4. The decolorization of Acid Red 18 and indigo carmine by DB104 (pSDJH-EA) spore. 
Table 1. Comparison of thermostability and effect of inhibitor on CotA activity at previous study.

\begin{tabular}{ccccc}
\hline \multirow{2}{*}{ Fusion protein } & Temp. stability & \multicolumn{3}{c}{ Effect of inhibitor on CotA decolorization activity } \\
\cline { 3 - 5 } & & EDTA $(\mathrm{mM})$ & $\mathrm{SDS}(\mathrm{mM})$ & $\mathrm{NaN}_{3}(\mathrm{mM})$ \\
\hline CotE-CotA $^{\mathrm{a}}$ & $70^{\circ} \mathrm{C}, 50 \%$ & $77 \%(25)$ & $20 \%(5)$ & $63 \%(5)$ \\
PgsA-CotA $^{\mathrm{b}}$ & $70^{\circ} \mathrm{C}, 90 \%$ & $13.3 \pm 3.2 \%(10)$ & $75.3 \pm 1.3 \%(1)$ & $5.5 \pm 2.35 \%(1)$ \\
& $90^{\circ} \mathrm{C}, 40 \%$ & & & \\
\hline
\end{tabular}

${ }^{a}$ Our research

${ }^{\mathrm{b}} 2018$ Yue Zhang et al.

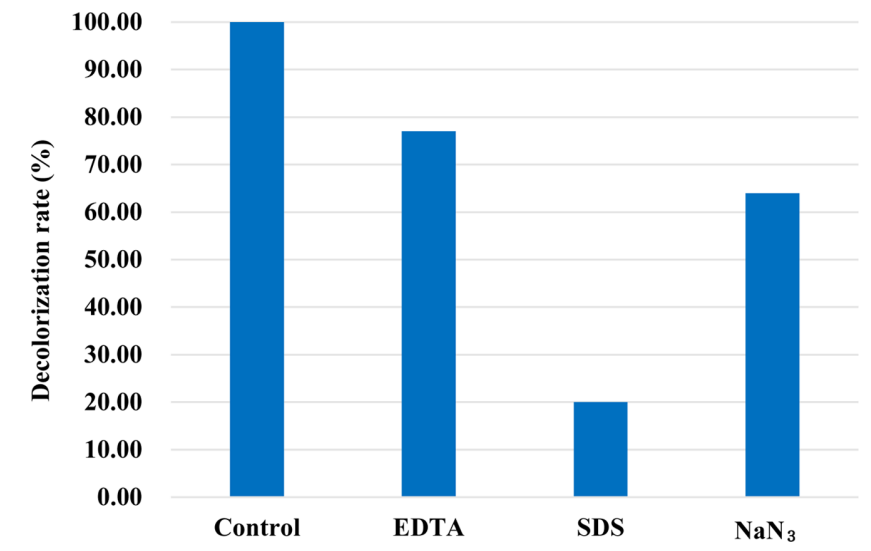

Fig. 5. Effect of inhibitors on the decolorization activity of recombinant DB104 (pSDJH-EA) spore.

EDTA and $\mathrm{NaN}_{3}$ are representative metal chelators, while SDS is a representative protein denaturation agent.

The decolorization activity of the recombinant spore decreased by $23 \%$ (EDTA), $80 \%$ (SDS), and $36 \%\left(\mathrm{NaN}_{3}\right)$ compared to the control DB104 spore without any inhibitor treatment. The inhibitory effect of EDTA was low even though it was used in abundance. SDS showed the highest inhibitory effect (Fig. 5)

Table 1 shows a comparison between our results and those of the previous studies performed with ABTS [23]. Despite the high concentration of EDTA and $\mathrm{NaN}_{3}$, the activity of spore surface-displayed $\cot A$ laccase was higher than that shown in a previous study. This could be attributed to the rigid structure of the spore.

\section{Effect of Temperature on Laccase Stability}

The decolorization rate increased with an increase in the temperature from $20^{\circ} \mathrm{C}$ to $50^{\circ} \mathrm{C}$. The decolorization activity at $50^{\circ} \mathrm{C}$ was the highest at $100 \%$. It decreased after $50^{\circ} \mathrm{C}$ and was $50 \%$ at $70^{\circ} \mathrm{C}$ (Fig. 6). One study has reported the thermal stability of surface-displayed $\cot A$ laccase using $p g s A$ in E. coli [23]. However, contrary to the expectations, the decolorization activity of cell surface-displayed $\cot A$ was

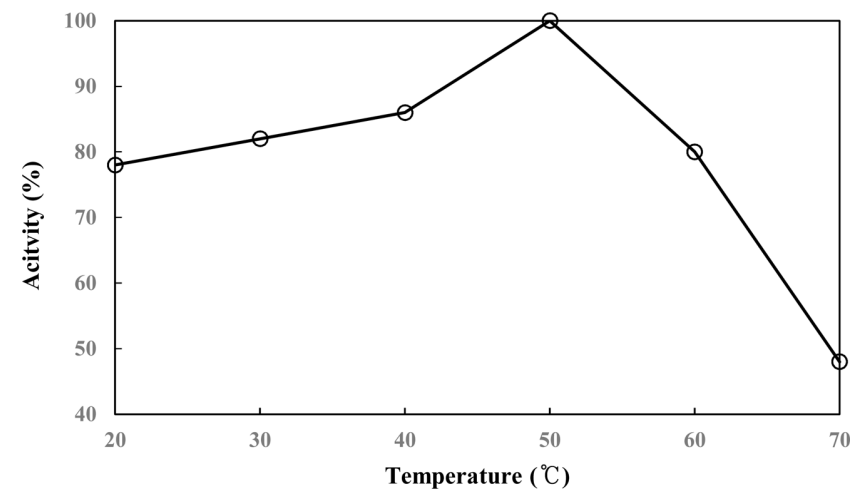

Fig. 6. Effect of temperature on the decolorization of Acid Green 25 using DB104 (pSDJH-EA) spore.

maintained at $40 \%$ at $90^{\circ} \mathrm{C}$, whereas that of our recombinant spore was reduced to $50 \%$ at $70^{\circ} \mathrm{C}$ (Table 1 ).

\section{Acknowledgments}

This work was supported by the Dong-A University research fund.

\section{Conflict of Interest}

The authors have no financial conflicts of interest to declare.

\section{References}

1. Keck A, Klein J, Kudlich M, Stolz A, Knackmuss H-J, Mattes R. 1997. Reduction of azo dyes by redox mediators originating in the naphthalenesulfonic acid degradation pathway of Sphingomonas sp. strain BN6. Appl. Environ. Microbiol. 63: 3684-3690.

2. Robinson T, McMullan G, Marchant R, Nigam P. 2001. Remediation of dyes in textile effluent: a critical review on current treatment technologies with a proposed alternative. Bioresour. Technol. 77: 247-255. 
3. Pandey A, Singh P, Iyengar L. 2007. Bacterial decolorization and degradation of azo dyes. Int. Biodeterior. Biodegradation 59: 73-84.

4. Zaharia C, Suteu D, Muresan A. 2012. Options and solutions for textile effluent decolorization using some specific physico-chemical treatment steps. Environ. Eng. Manag. J. 11: 493-509.

5. Cho EA, Seo J, Lee DW, Pan JG. 2011. Decolorization of indigo carmine by laccase displayed on Bacillus subtilis spores. Enzyme Microb Technol. 49: 100-104.

6. Giardina P, Faraco V, Pezzella C, Piscitelli A, Vanhulle S, Sannia G. 2010. Laccases: a never-ending story. Cell Mol. Life Sci. 67: 369-385.

7. Yoshida H. 1883. LXIII.-chemistry of lacquer (Urushi). Part I. communication from the chemical society of Tokio. J. Chem. Soc. Trans. 43: 472-486.

8. Lončar N, Božić N, Lopez-Santin J, Vujčić Z. 2013. Bacillus amyloliquefaciens laccase-from soil bacteria to recombinant enzyme for wastewater decolorization. Bioresour. Technol. 147: $177-183$.

9. Riva S. 2006. Laccases: blue enzymes for green chemistry. Trends Biotechnol. 24: 219-226.

10. Widsten P, Kandelbauer A. 2008. Laccase applications in the forest products industry: a review. Enzyme Microb. Technol. 42: 293-307.

11. Givaudan A, Effosse A, Faure D, Potier P, Bouillant M-L, Bally R. 1993. Polyphenol oxidase in Azospirillum lipoferum isolated from rice rhizosphere: evidence for laccase activity in non-motile strains of Azospirillum lipoferum. FEMS Microbiol. Lett. 108: 205-210.

12. Sharma P, Goel R, Capalash N. 2007. Bacterial laccases. World J. Microbiol. Biotechnol. 23: 823-832.

13. Cha JS, Cooksey DA. 1991. Copper resistance in Pseudomonas syringae mediated by periplasmic and outer membrane proteins. Proc. Natl. Acad. Sci. USA 88: 8915-8919.

14. Hsiao YM, Liu YF, Lee PY, Hsu PC, Tseng SY, Pan YC. 2011. Functional characterization of copA gene encoding multicopper oxidase in Xanthomonas campestris pv. campestris. J. Agric. Food Chem. 59: 9290-9302.

15. Diamantidis G, Effosse A, Potier P, Bally R. 2000. Purification and characterization of the first bacterial laccase in the rhizospheric bacterium Azospirillum lipoferum. Soil Biol. Biochem. 32: 919-927.

16. Endo K, Hayashi Y, Hibi T, Hosono K, Beppu T, Ueda K. 2003. Enzymological characterization of EpoA, a laccase-like phenol oxidase produced by Streptomyces griseus. J. Biochem. 133: 671-677.

17. Roberts SA, Weichsel A, Grass G, Thakali K, Hazzard JT, Tollin G, et al. 2002. Crystal structure and electron transfer kinetics of $\mathrm{CueO}$, a multicopper oxidase required for copper homeostasis in Escherichia coli. Proc. Natl. Acad. Sci. USA 99: 2766-2771.
18. Durao P, Chen Z, Fernandes AT, Hildebrandt P, Murgida $\mathrm{DH}$, Todorovic S, et al. 2008. Copper incorporation into recombinant CotA laccase from Bacillus subtilis: characterization of fully copper loaded enzymes. J. Biol. Inorg. Chem. 13: 183193.

19. Dube E, Shareck F, Hurtubise Y, Daneault C, Beauregard M. 2008. Homologous cloning, expression, and characterisation of a laccase from Streptomyces coelicolor and enzymatic decolourisation of an indigo dye. Appl. Microbiol. Biotechnol. 79: 597-603.

20. Gopinath KP, Murugesan S, Abraham J, Muthukumar K. 2009. Bacillus sp. mutant for improved biodegradation of Congo red: random mutagenesis approach. Bioresour. Technol. 100: 6295-6300.

21. Wu J, Kim K-S, Sung N-C, Kim C-H, Lee Y-C. 2009. Isolation and characterization of Shewanella oneidensis WL-7 capable of decolorizing azo dye reactive Black 5. J. Gen. Appl. Microbiol. 55: 51-55.

22. Kalyani DC, Telke AA, Govindwar SP, Jadhav JP. 2009. Biodegradation and detoxification of reactive textile dye by isolated Pseudomonas sp. SUK1. Water Environ. Res. 81: 298307.

23. Zhang Y, Dong W, Lv Z, Liu J, Zhang W, Zhou J, et al. 2018. Surface display of bacterial Laccase CotA on Escherichia coli cells and its application in industrial dye decolorization. Mol. Biotechnol. 60: 681-689.

24. Freudl R, MacIntyre S, Degen M, Henning U. 1986. Cell surface exposure of the outer membrane protein OmpA of Escherichia coli K-12. J. Mol. Biol. 188: 491-494.

25. Kim J, Schumann W. 2009. Display of proteins on Bacillus subtilis endospores. Cell Mol. Life Sci. 66: 3127-3136.

26. Kondo A, Ueda M. 2004. Yeast cell-surface display-applications of molecular display. Appl. Microbiol Biotechnol. 64: 28-40.

27. Ventura M, Jankovic I, Walker DC, Pridmore RD, Zink R. 2002. Identification and characterization of novel surface proteins in Lactobacillus johnsonii and Lactobacillus gasseri. Appl. Environ. Microbiol. 68: 6172-6181.

28. Eichenberger P, Fujita M, Jensen ST, Conlon EM, Rudner DZ, Wang ST, et al. 2004. The program of gene transcription for a single differentiating cell type during sporulation in Bacillus subtilis. PLoS Biol. 2: e328.

29. Kim JH, Lee CS, Kim BG. 2005. Spore-displayed streptavidin: a live diagnostic tool in biotechnology. Biochem. Biophys. Res. Commun. 331: 210-214.

30. Sunde EP, Setlow P, Hederstedt L, Halle B. 2009. The physical state of water in bacterial spores. Proc. Natl. Acad. Sci. USA 106: 19334-19339.

31. Kawamura F, Doi RH. 1984. Construction of a Bacillus subtilis double mutant deficient in extracellular alkaline and neutral proteases. J. Bacteriol. 160: 442-444.

32. Kim J-H, Choi S-K, Jung H-C, Pan J-G, Kim B-G. 2011. Bacterial surface display of Levansucrase of Zymomonas 
mobilis using Bacillus Subtilis spore display system. KSBB J. 26: 243-247.

33. Asgher M, Yasmeen Q, Iqbal HM. 2013. Enhanced decolorization of Solar brilliant red 80 textile dye by an indigenous white rot fungus Schizophyllum commune IBL-06. Saudi J. Biol. Sci. 20: 347-352.

34. Guoyan Z, Yingfeng A, Zabed H, Qi G, Yang M, Jiao Y, et al. 2019. Bacillus subtilis spore surface display technology: A review of its development and applications. J. Microbiol. Biotechnol. 29: 179-190.

35. Little S, Driks A. 2001. Functional analysis of the Bacillus subtilis morphogenetic spore coat protein CotE. Mol. Microbiol. 42: $1107-1120$

36. Hwang B-Y, Pan J-G, Kim B-G, Kim J-H. 2013. Functional display of active tetrameric $\beta$-galactosidase using Bacillus subtilis spore display system. J. Nanosci. Nanotechnol. 13: 2313-2319.

37. Hosseini?Abari A, Kim BG, Lee SH, Emtiazi G, Kim W, Kim JH. 2016. Surface display of bacterial tyrosinase on spores of Bacillus subtilis using CotE as an anchor protein. J. Basic Microbiol. 56: 1331-1337.

38. Giglio R, Fani R, Isticato R, De Felice M, Ricca E, Baccigalupi L. 2011. Organization and evolution of the cotG and cotH genes of Bacillus subtilis. J. Bacteriol. 193: 66646673.

39. Laaberki MH, Dworkin J. 2008. Role of spore coat proteins in the resistance of Bacillus subtilis spores to Caenorhabditis elegans predation. J. Bacteriol. 190: 6197-6203.

40. Hwang B-Y, Kim B-G, Kim J-H. 2011. Bacterial surface display of a co-factor containing enzyme, $\omega$-transaminase from vibrio fluvialis using the Bacillus subtilis spore display system. Biosci. Biotechnol. Biochem. 75: 1862-1865.

41. Rostami A, Hinc K, Goshadrou F, Shali A, Bayat M, Hassanzadeh M, et al. 2017. Display of B. pumilus chitinase on the surface of $B$. subtilis spore as a potential biopesticide. Pestic. Biochem. Physiol. 140: 17-23.

42. Guo Q, An Y, Yun J, Yang M, Magocha TA, Zhu J, et al. 2018. Enhanced d-tagatose production by spore surfacedisplayed 1-arabinose isomerase from isolated Lactobacillus brevis PC16 and biotransformation. Bioresour. Technol. 247: 940-946.

43. McKenney PT, Driks A, Eskandarian HA, Grabowski P, Guberman J, Wang KH, et al. 2010. A distance-weighted interaction map reveals a previously uncharacterized layer of the Bacillus subtilis spore coat. Curr. Biol. 20: 934-938.
44. Liu H, Krajcikova D, Zhang Z, Wang H, Barak I, Tang J. 2015. Investigating interactions of the Bacillus subtilis spore coat proteins CotY and CotZ using single molecule force spectroscopy. J. Struct. Biol. 192: 14-20.

45. Wang H, Yang R, Hua X, Zhao W, Zhang W. 2015. Functional display of active $\beta$-galactosidase on Bacillus subtilis spores using crust proteins as carriers. Food Sci. Biotechnol. 24: 1755-1759.

46. Ghasemi Y, Yarahmadi E, Ghoshoon M, Dabbagh F, Hajighahramani N, Ebrahimi N, et al. 2014. Cloning, expression and purification of laccase enzyme gene from Bacillus subtilis in Escherichia coli. Minerva Biotechnol. 26: 295-300.

47. Hullo M-F, Moszer I, Danchin A, Martin-Verstraete I. 2001. CotA of Bacillus subtilis is a copper-dependent laccase. J. Bacteriol. 183: 5426-5430.

48. Benkhaya S, El Harfi S, El Harfi A. 2017. Classifications, properties and applications of textile dyes: A review. Appl. J. Environ. Eng. Sci. 3: 311-320.

49. Wang W, Zhang Z, Ni H, Yang X, Li Q, Li L. 2012. Decolorization of industrial synthetic dyes using engineered Pseudomonas putida cells with surface-immobilized bacterial laccase. Microb. Cell Fact. 11: 75.

50. Murugesan K, Arulmani M, Nam IH, Kim YM, Chang YS, Kalaichelvan PT. 2006. Purification and characterization of laccase produced by a white rot fungus Pleurotus sajor-caju under submerged culture condition and its potential in decolorization of azo dyes. Appl. Microbiol. Biotechnol. 72: 939-946.

51. Cho E-A, Seo J, Lee D-W, Pan J-G. 2011. Decolorization of indigo carmine by laccase displayed on Bacillus subtilis spores. Enzyme Microb. Technol. 49: 100-104.

52. Wang T-N, Zhao M. 2017. A simple strategy for extracellular production of CotA laccase in Escherichia coli and decolorization of simulated textile effluent by recombinant laccase. Appl. Microbiol. Biotechnol. 101: 685-696.

53. Guo H, Zheng B, Jiang D, Qin W. 2017. Overexpression of a laccase with dye decolorization activity from Bacillus sp. induced in Escherichia coli. J. Mol. Microbiol. Biotechnol. 27: 217-227.

54. Enguita FJ, Matias PM, Martins LO, Placido D, Henriques AO, Carrondo MA. 2002. Spore-coat laccase $\operatorname{CotA}$ from Bacillus subtilis: crystallization and preliminary X-ray characterization by the MAD method. Acta Crystallogr. D Biol. Crystallogr. 58(Pt 9): 1490-1493.

55. Couto SR, Herrera L. 2006. Inhibitors of laccases: a review. Curr. Enzym. Inhib. 2: 343-352. 